\title{
CARBON AND BIOMASS STOCKS IN A FRAGMENT OF CERRADÃO IN MINAS GERAIS STATE, BRAZIL
}

\author{
Vinícius Augusto Morais ${ }^{1}$, José Roberto Soares Scolforo ${ }^{2}$, Carlos Alberto Silva ${ }^{3}$, \\ José Marcio de Mello², Lucas Rezende Gomide², Antônio Donizette de Oliveira²
}

(received: May 9, 2011; accepted: December 21, 2012)

\begin{abstract}
This study aimed at quantifying carbon $(\mathrm{C})$ and biomass stocks in shoot portion, leaf litter, roots and soil within a fragment of dense savanna 'cerradão', 158.5 ha in area, located in Minas Gerais state. Measures were quantified using dendrometric parameters obtained during the forest inventory and collection of leaf litter, root and soil samples. Furrows were dug in the soil each $100 \mathrm{~cm}$ long, $50 \mathrm{~cm}$ wide and $100 \mathrm{~cm}$ deep in order to collect root samples at depths of 0-30 cm, 30-50 cm and 50-100 $\mathrm{cm}$, and soil samples from the layers $0-10 \mathrm{~cm}, 10-20 \mathrm{~cm}, 20-40 \mathrm{~cm}, 40-60 \mathrm{~cm}$ and $60-100 \mathrm{~cm}$, as well as any leaf litter from the surrounding surface. Analyses were performed in the Organic Matter Study Laboratory (DCS/UFLA) to determine C contents in the above matrices, using an Elementar analyzer model Vario TOC Cube. Higher C contents and stocks and lower density were noted in topmost soil layers. In cerradão, shoot portion was found to be the matrix contributing the most to biomass production, followed by roots and leaf litter. Carbon stock in the fragment was $139.7 \mathrm{Mg} \mathrm{ha}^{-1}$. Soil was the matrix contributing the most to stocked C (64.8\%), followed by the shoot portion (26.3\%), roots $(5.2 \%)$ and leaf litter $(3.7 \%)$.
\end{abstract}

Key words: Forest inventory, carbon sequestration, cerrado, biomass, leaf litter.

\section{ESTOQUES DE CARBONO E BIOMASSA DE UM FRAGMENTO DE CERRADÃO EM MINAS GERAIS, BRASIL}

RESUMO: Este trabalho foi desenvolvido para quantificar o estoque de carbono $(C)$ e biomassa presente na parte aérea lenhosa, serrapilheira, raizes e solos, num fragmento de cerradão com 158,5 ha, em Minas Gerais. As quantificações foram realizadas por meio de medidas dendrométricas tomadas durante o inventário florestal e de coleta de amostras de serrapilheira, raizes e solo. No solo, foram perfuradas trincheiras de $100 \mathrm{~cm}$ de comprimento, $50 \mathrm{~cm}$ de largura e $100 \mathrm{~cm}$ de profundidade, onde foram coletadas as raizes, nas profundidades de 0 a 30, 30 a 50 e 50 a $100 \mathrm{~cm}$, amostras de solo, nas camadas de 0 a 10, 10 a 20, 20 a 40, 40 a 60, e 60 a 100 cm, bem como toda serrapilheira da superfície da trincheira. As análises dos teores de $C$, nas matrizes mencionadas, foram realizadas no Laboratório de Estudo da Matéria Orgânica, DCS/UFLA, utilizandose um analisador Elementar modelo Vario TOC Cube. Os maiores teores e estoques de $C$ e a menor densidade são notados nas camadas superficiais de solo. No cerradão, a parte aérea arbórea é a matriz que mais contribui para a produção de biomassa, seguida pelas raizes e serrapilheira. O estoque de carbono no fragmento de cerradão foi de $139,7 \mathrm{Mg} \mathrm{ha}^{-1}$; o solo é matriz que mais contribui para esse C armazenado (64,8\%), seguido pela parte arbórea lenhosa (26,3\%), raizes (5,2\%) e serrapilheira $(3,7 \%)$.

Palavras-chave: Inventário florestal, sequestro de carbono, cerrado, biomassa, serrapilheira.

\section{INTRODUCTION}

The cerrado biome occupies around 2 million $\mathrm{Km}^{2}$ in area and is the second largest vegetation unit in Brazil (LIMA et al., 2009), accounting for an expressive fraction of the Earth's ecosystems (ADUAN et al., 2003). This highly representative vegetation of Brazil is found in 15 states, including the Federal District (MARIMON JUNIOR; HARIDASAN, 2005). In Minas Gerais alone, the cerrado covers $12,290,460.0$ ha, with variations that include campo, campo rupestre, campo cerrado, cerrado, cerradão, and vereda (CARVALHO, L. M. et al., 2008). Rufini et al. (2010) argue that in recent years, due to anthropic activities such as urban and agricultural expansion, infrastructure and mineral production, the rate of deforestation and destruction of the cerrado has been on the rise, to a point where about $80 \%$ of the biome has already been destroyed (REZENDE et al., 2006), with

${ }^{1}$ Forest Engineer, PhD candidate in Forest Engineering - Universidade Federal de Lavras/UFLA - Departamento de Ciências Florestais Programa de Pós-Graduação em Engenharia Florestal - Cx. P. 3037 - 37200-000 - Lavras, MG, Brasil - vemorais@bol.com.br ${ }^{2}$ Forest Engineer, Professor, PhD in Forest Engineering - Universidade Federal de Lavras/UFLA - Departamento de Ciências Florestais - Cx. P. 3037-37200-000 - Lavras, MG, Brasil - jscolforo@dcf.ufla.br, josemarcio@dcf.ufla.br, lucasgomide@dcf.ufla.br, donizette@dcf.ufla.br ${ }^{3}$ Agronomic Engineer, Professor, PhD in Agronomy/Soils and Plant Nutrition - Universidade Federal de Lavras/UFLA - Departamento de Ciência do Solo - Cx. P. 3037 - 37200-000 - Lavras, MG, Brasil - csilva@dcs.ufla.br

Cerne, Lavras, v. 19, n. 2, p. 237-245, abr./jun. 2013 
hardly any knowledge about carbon stocks in the soilplant system or about most suitable methodologies to quantify the carbon stocked in this important Brazilian ecosystem.

Cerradão is a rare type of forest vegetation that once occupied only $1 \%$ of the cerrado areas of Brazil, known for being recurrent in dystrophic and mesotrophic soils and for having variable floristic composition according to local soil fertility (MARIMON JUNIOR; HARIDASAN, 2005). Tree and shrub species predominate in that floristic group, forming a dense, continuous canopy layer (CAMPOS et al., 2006; SOUZA et al., 2010), which implies greater biomass production and higher $\mathrm{C}$ storage than other cerrado ecotypes.

In forest ecosystems, it is in the soil that greater carbon stocks are found. Fernandes and Fernandes (2009), adapted from Jantalia et al. (2006), found 81.9 $\mathrm{Mgha}^{-1}$ of $\mathrm{C}$ in cerrado soil in the $0-40 \mathrm{~cm}$ layer, and 24.18 $\mathrm{Mgha}^{-1}$ of $\mathrm{C}$ in cerradão soil of the Pantanal, in the same layer (FERNANDES et al., 1999). Melo and Durigan (2006) obtained estimates of $50 \mathrm{Mgha}^{-1}$ for carbon stocked in the soil of native Brazilian cerrado. Scolforo et al. (2008a) studied five cerradão fragments in Minas Gerais and estimated values that range from 27.5 $\mathrm{Mgha}^{-1}$ to $45.1 \mathrm{Mgha}^{-1}$ of $\mathrm{C}$ for the shoot portion of cerradão. Roots are main entry points of carbon in the soil. Paiva and Faria (2007) found $46.63 \mathrm{Mg} \mathrm{ha}^{-1}$ of root biomass in the $0-2 \mathrm{~m}$ soil layer, and $22.38 \mathrm{Mg} \mathrm{ha}^{-1}$ of C in the same layer, for a cerrado sensu stricto fragment located in the Federal District. As regards leaf litter, which is the compartment contributing the least to carbon stock, Aduan et al. (2003) studied different floristic communities of the cerrado and found carbon stocks, as adapted from Ottmar et al. (2001), of 0.10, 0.37, 0.97 and $0.97 \mathrm{Mgha}^{-1}$ of C for campo limpo, campo sujo, cerrado sensu stricto and cerrado denso respectively, noting that these areas had been subjected to forest burnings more than a year prior to data collection.

According to Aduan et al. (2003), knowledge of carbon cycles in the cerrado ecosystem is yet rudimentary, particularly its stock and flow patterns, on account of the shortage of timely, accurate estimates. These authors also point out that literature available on Brazilian cerrado is scarce and fragmented.

With the above in mind, this study aimed to quantify biomass and carbon stocks in shoot portion, leaf litter, roots and soil of a cerradão fragment located in Limeira do Oeste, Minas Gerais state.

Cerne, Lavras, v. 19, n. 2, p. 237-245, abr./jun. 2013

\section{MATERIAL AND METHODS}

The study was performed in a cerradão fragment, 158.5 ha in size, located at central coordinate $19^{\circ} 31^{\prime} 65^{\prime} \mathrm{S}$ and $50^{\circ} 39^{\prime} 65^{\prime} \mathrm{W}$ (Figure 1 ), in the municipality of Limeira do Oeste, Minas Gerais. According to local climate zoning and based on Thornthwaite moisture index (TMI), the fragment falls into the $\mathrm{B}_{2}$-humid class group, with a moisture index of $40 \%$ to $60 \%$, an average temperature between $19^{\circ} \mathrm{C}$ and $20^{\circ} \mathrm{C}$, and total accumulated precipitation in the range of $1,500 \mathrm{~mm}$ to $1,600 \mathrm{~mm}$. Potential evapotranspiration is relatively low, with an annual water deficit in the agricultural soil of around $87 \mathrm{~mm}$ (CARVALHO, L. G. et al., 2008).

The predominant local soil is Latosol, characterized as being a deep, highly weathered soil, naturally with low fertility and typically with good physical properties (CURI et al., 2008).

A forest inventory was compiled for the fragment in February 2010, comprising 30 plots, each $1000 \mathrm{~m}^{2}$ in area, to a total of 3 ha. Dendrometric variables being measured included total height and DBH (diameter $1.30 \mathrm{~m}$ aboveground) of every plant having a $\mathrm{DBH} \geq 5$ $\mathrm{cm}$. Inventory data were processed by software SISNAT (SCOLFORO et al., 2003), using the volume equation proposed by Scolforo et al. (2008b), for this floristic community, which derived an adjusted $\mathrm{R}^{2}$ of $98.78 \%$, a Syx of $0.13848 \mathrm{~m}^{3}$ and a Syx (\%) of 26.07. The equation is given as follows:

$V o l=\exp (-9.7003574958+2.3603328234 * \operatorname{Ln}(D B H)+$ $0.5063592154 * \operatorname{Ln}(H t))$

Where: $\mathrm{DBH}=$ diameter at breast height $(1.30 \mathrm{~m}$ aboveground) $(\mathrm{cm}), \mathrm{Ht}=$ total height $(\mathrm{m}), \mathrm{Vol}=$ volume outside bark $\left(\mathrm{m}^{3}\right), \exp =$ exponential, $\mathrm{Ln}=$ natural logarithm.

The carbon stock present in the shoot portion up to $3 \mathrm{~cm}$ was quantified as $\mathrm{Mg} \mathrm{ha}^{-1}$ using the equation proposed by Scolforo et al. (2008c). Model fitting provided the following measures of accuracy: an adjusted $\mathrm{R}^{2}$ of $93.33 \%$ and a Syx of $51.33 \%$.

$C=\exp (-10.9925732677+2.2705953017 * \operatorname{Ln}(D b h)+$ $0.5646506234 * \operatorname{Ln}(H t))$

Where: DBH, Ht, exp, $\mathrm{Ln}=$ as defined previously, $\mathrm{C}=$ carbon stock $(\mathrm{Mg})$. 

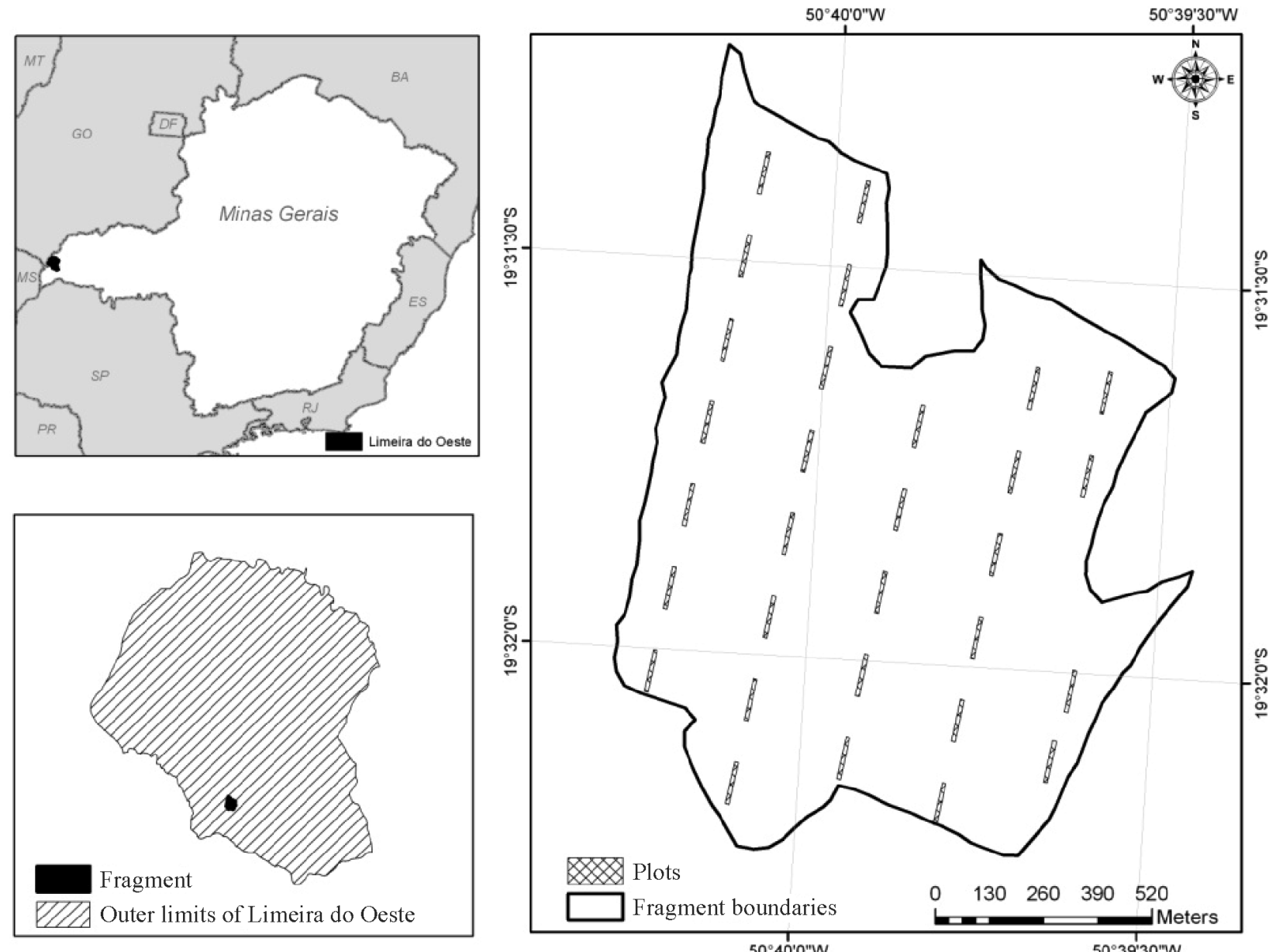

Figure 1 - Location map of the study site.

Figura 1 - Mapa de localização da área de estudo.

After distributing the plots and compiling the forest inventory, $30 \%$ of the plots were randomly selected in which were collected leaf litter, root and soil matrices for $\mathrm{C}$ determination. In each selected plot, positions were randomly selected with the relevant horizontal (width) and vertical (length) distance to leaf litter, root and soil sampling points. The sampling points were positioned somewhere within $0-10 \mathrm{~m}$ widthwise and $10-100 \mathrm{~m}$ lengthwise, obtaining two subplots per plot (Figure 2). Random selection of the lengthwise distance started from $10 \mathrm{~m}$ onward, as a regrowth study is taking place in the $0-10 \mathrm{~m}$ interval.

The litter, root and soil samples were collected in March and April 2010. For litter sampling, a $0.5 \mathrm{~m}^{2}$ $(0.5 \mathrm{~m} \times 1 \mathrm{~m})$ template was used with which all existing material was collected. The same template was used for root sampling, yet here a furrow $100 \mathrm{~cm}$ deep was dug. The root material was separated according to soil depth, namely the layers $0-30 \mathrm{~cm}, 30-50 \mathrm{~cm}$ and $50-100 \mathrm{~cm}$, noting that root sorting also followed thickness classes, namely $<5 \mathrm{~mm}, 5.1-10 \mathrm{~mm}$ and $>10 \mathrm{~mm}$.

Both leaf litter and root samples were stored in paper bags, each labeled with fragment name and plot number. Bags with root samples were additionally labeled with soil depth and thickness class. The samples were washed and dried at $65-70^{\circ} \mathrm{C}$ in a forced-air oven to a constant weight, then weighed to determine dry biomass $(\mathrm{g})$, crushed by a knife mill and then sieved $(0.250 \mathrm{~mm}$ sieve). The analysis of root samples focused specifically on carbon stocks at different soil depths, rather than separating them by diameter class.

Cerne, Lavras, v. 19, n. 2, p. 237-245, abr./jun. 2013 


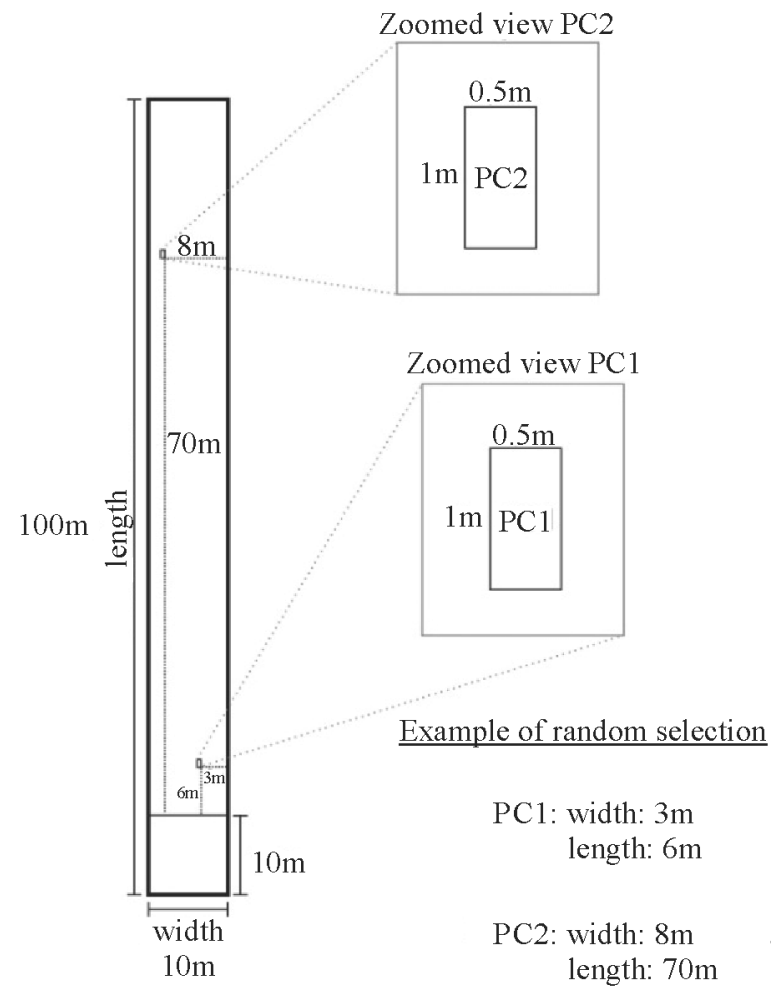

Figure 2 - Graphic illustration of the randomly selected sampling points.

Figura 2 - Esquema da parcela com os pontos amostrais sorteados.

The same procedure as above was adopted for soil sampling, only at different depths, namely the layers $0-10 \mathrm{~cm}, 10-20 \mathrm{~cm}, 20-40 \mathrm{~cm}, 40-60 \mathrm{~cm}$, and $60-100 \mathrm{~cm}$. All material being sampled was stored in plastic bags labeled with plot number and sampling depth. The soil samples were macerated in a porcelain mortar using a pestle, then air-dried and sieved $(0.250 \mathrm{~mm}$ sieve). The local soils are typically sandy $(79.67 \%$ sand, $18.22 \%$ clay and $2.11 \%$ silt) and acidic, providing average values of $\mathrm{pH}$ in water of $4.89,0.74 \mathrm{cmol} / \mathrm{dm}^{3}$ of $\mathrm{Ca}^{2+}, 0.55 \mathrm{cmol} / \mathrm{dm}^{3}$ of $\mathrm{Mg}^{2+}$, $0.54 \mathrm{cmol} / \mathrm{dm}^{3}$ of $\mathrm{Al}^{3+}, 61.03 \mathrm{mg} / \mathrm{dm}^{3}$ of $\mathrm{Fe}^{2+}, 30.65 \mathrm{mg} /$ $\mathrm{dm}^{3}$ of $\mathrm{Mn}^{2+}, 0.37 \mathrm{mg} / \mathrm{dm}^{3}$ of $\mathrm{Zn}^{2+}, 0.09 \mathrm{mg} / \mathrm{dm}^{3}$ of B, and base saturation of $26 \%$.

During soil sampling for density determination, a volumetric metal ring $82.643741 \mathrm{~cm}^{3}$ in volume was used. Soil samples were collected from the same depths as established for analysis of carbon percentage, being dried at a $105^{\circ} \mathrm{C}$ and weighed. Density $\left(\mathrm{cm}^{3}\right)$ was derived for each sampling depth based on sample weight and volume.
Because litter, root and soil were sampled from two sampling points, the option of choice was to form one composite sample per plot, yet observing depth and thickness in the case of root samples.

After being processed, the material was sent to the Organic Matter Study Laboratory of the Federal University of Lavras, for determination of the carbon percentage in each sample. Analyzes were performed using an Elementar analyzer, model Vario TOC Cube. In the carbon meter, $10-20 \mathrm{mg}$ of soil sample was used, as well as $1.5-6 \mathrm{mg}$ of leaf litter and root samples. The samples were placed in tin capsules and injected in a dry combustion chamber at $950^{\circ} \mathrm{C}$. The evolved $\mathrm{CO}_{2}$ gas from each sample was quantified in a NDIR infrared sensor, correlating the evolved carbon with the weight unit of the sample.

The organic carbon stock in the soil was quantified as mega gram per hectare $\left(\mathrm{Mg} \mathrm{ha}^{-1}\right)$, for each layer ampled. In this calculation, the expression proposed by Veldkamp (1994) was used:

$S t C=(C O x S d x t)$

where: $\mathrm{StC}=$ organic carbon stock at a given depth $\left(\mathrm{Mg} \mathrm{ha}^{-1}\right)$, $\mathrm{CO}=$ total organic carbon content at the depth sampled $(\%), \mathrm{Sd}=$ soil density at the depth sampled $\left(\mathrm{g} / \mathrm{cm}^{3}\right), \mathrm{t}=$ thickness of soil layer $(\mathrm{cm})$.

The carbon stock present in leaf litter and in roots was quantified as $\mathrm{Mg} \mathrm{ha}^{-1}$ of $\mathrm{C}$, as a function of dry biomass and $\mathrm{C}$ content of each sample. The biomass value was extrapolated to 1 ha and, subsequently, depending on the carbon content present, the $\mathrm{C}$ stock was derived. Descriptive statistics was adopted for data analysis, evaluating the following parameters: mean, standard deviation, coefficient of variation, maximum and minimum values.

\section{RESULTS AND DISCUSSION}

Data in Table 1 reveal that results are consistent with values found by Scolforo et al. (2008a) in a study comprising five cerradão fragments in Minas Gerais in assorted regrowth and density stages, which provided mean values of 1649.01 plants $/$ ha, $17.58 \mathrm{~m}^{2} /$ ha of basal area, $117.49 \mathrm{~m}^{3} / \mathrm{ha}$ of volume and $56.32 \mathrm{t} / \mathrm{ha}$ of dry matter.

The similar variability in carbon, volume and dry weight is due to the direct correlation of these variables in calculation of carbon. 
Table 1 - Dendrometric data, including density, basal area, volume and dry weight for a forest fragment in Minas Gerais.

Tabela 1 - Informações dendrométricas de densidade, área basal, volume e peso de matéria seca de um fragmento florestal em Minas Gerais.

\begin{tabular}{lcccc}
\hline Statistics & Trees/ha & $\begin{array}{c}\text { Basal area } \\
\left(\mathrm{m}^{2} / \mathrm{ha}\right)\end{array}$ & $\begin{array}{c}\text { Volume } \\
\left(\mathrm{m}^{3}\right)\end{array}$ & $\begin{array}{c}\text { Dry } \\
\text { weight } \\
(\mathrm{Mg} / \mathrm{ha})\end{array}$ \\
\hline Mean & 1006.33 & 15.42 & 127.22 & 70.49 \\
Maximum & 1620.00 & 23.70 & 256.50 & 144.50 \\
Minimum & 620.00 & 7.30 & 41.30 & 23.00 \\
SD & 229.43 & 3.78 & 51.82 & 29.07 \\
$\mathrm{CV}(\%)$ & 22.80 & 24.51 & 40.73 & 41.24 \\
\hline
\end{tabular}

$\mathrm{SD}=$ standard deviation; $\mathrm{CV}=$ coefficient of variation.

\subsection{Carbon stock - Shoot portion}

Carbon stocks were quantified separately in each of the four compartments, namely shoot portion, leaf litter, roots and soil. The shoot portion stocks $36.78 \mathrm{Mg}$ $\mathrm{ha}^{-1}$ of $\mathrm{C}$ on average, with a minimum $\mathrm{C}$ value of 16.42 $\mathrm{Mg} \mathrm{ha}^{-1}$, a maximum $\mathrm{C}$ value of $68.20 \mathrm{Mg} \mathrm{ha}^{-1}$, standard deviation of $17.48 \mathrm{Mg} \mathrm{ha}^{-1}$ and coefficient of variation of $47.52 \%$. Scolforo et al. (2008a) studied five cerradão fragments in Minas Gerais and found estimated values ranging from $27.5 \mathrm{Mg} \mathrm{ha}^{-1}$ to $45.1 \mathrm{Mg} \mathrm{ha}^{-1}$ of $\mathrm{C}$, with mean values of $35.08 \mathrm{Mg} \mathrm{ha}^{-1}$ of $\mathrm{C}$, very close to the findings in this study.

The coefficients of simple linear correlation between volume, dry weight and carbon stock were 0.9994 , 0.99989 and 0.92173 respectively. This correlation is an evidence of the strong participation of these variables in estimation of carbon stock.

\subsection{Carbon stock - Leaf litter}

As for leaf litter, the mean dry biomass output was found to be $11.67 \mathrm{Mg} \mathrm{ha}^{-1}$, with a mean carbon content of $45.94 \%$. The product of $\mathrm{C}$ content and biomass is carbon stock, which in this matrix provided a mean stock of 5.36 $\mathrm{Mg} \mathrm{ha}^{-1}$ (Table 2).

Table 2 reveals a high coefficient of variation (91.79\%) for carbon stock. However, variability in carbon content was low $(2.93 \%)$. Variation in carbon stock is significantly affected by volume and dry weight. According to Scolforo et al. (2008c), carbon content in the shoot portion is in the range of $48 \%$, close to values found in this study.
Table 2 - Descriptive statistics of biomass, carbon stock and carbon content in leaf litter of a forest fragment.

Tabela 2 - Estatísticas descritivas de biomassa, estoque e teor de carbono na serrapilheira de um fragmento florestal.

\begin{tabular}{lccc}
\hline Statistics & $\begin{array}{c}\text { Biomass } \\
(\mathrm{Mg} / \mathrm{ha})\end{array}$ & $\begin{array}{c}\mathrm{C} \text { content } \\
(\%)\end{array}$ & $\begin{array}{c}\text { Carbon stock } \\
(\mathrm{Mg} / \mathrm{ha})\end{array}$ \\
\hline Mean & 11.67 & 45.94 & 5.36 \\
Maximum & 19.31 & 47.80 & 8.88 \\
Minimum & 4.86 & 43.80 & 2.28 \\
Standard Deviation & 4.00 & 1.35 & 4.92 \\
CV (\%) & 34.27 & 2.93 & 91.79 \\
\hline
\end{tabular}

$\mathrm{CV}=$ coefficient of variation.

\subsection{Carbon stock - Roots}

The analysis of biomass production in the soil layer $0-100 \mathrm{~cm}$ revealed that roots had a mean dry biomass of $16.38 \mathrm{Mg} \mathrm{ha}^{-1}$, with a mean carbon content of $44.76 \%$ and a stock of $7.30 \mathrm{Mgha}^{-1}$, standard deviation of $2.25 \mathrm{MgC} \mathrm{ha}^{-1}$, maximum value of $10.80 \mathrm{MgC} \mathrm{ha}^{-1}$, minimum value of 4.44 $\mathrm{MgC} \mathrm{ha-1}$ and coefficient of variation of $30.85 \%$. The high coefficient of variation is due to each sample being formed by miscellaneous roots from various species. Paiva and Faria (2007) found a root biomass value of $46.63 \mathrm{Mg} \mathrm{ha}^{-1}$ and a carbon stock of $22.38 \mathrm{Mg} \mathrm{ha}^{-1}$, considering a soil depth up to $200 \mathrm{~cm}$, in cerrado stricto sensu of the Federal District, yet their estimates were based on collections up to $30 \mathrm{~cm}$ deep and using a depth conversion factor, which potentially results in inaccuracies when calculating total stock.

In roots, a higher carbon stock was found in the topmost soil layer, 0-30 cm, followed by layers $30-50 \mathrm{~cm}$ and $50-100 \mathrm{~cm}$, with $\mathrm{C}$ stock percentages of $59.73 \%$, $23.01 \%$ and $17.27 \%$ respectively for the $0-100 \mathrm{~cm}$ depth interval. According to Aduan et al. (2003), in cerrado, 80\% of the root biomass occurs along the topmost $30 \mathrm{~cm}$ soil layer, which explains the greater amount of carbon being stocked in the surface layer than in subsequent layers. In studying soil of the Brazilian cerrado, Abdala et al. (1998) collected root samples up to $6.2 \mathrm{~m}$ deep and found a biomass stock of $33.4 \mathrm{Mg} \mathrm{ha}^{-1}$, with $80 \%$ of residue being found in the $0-100 \mathrm{~cm}$ layer.

\subsection{Carbon stock - Soil}

Soil holds higher carbon stocks than other compartments of a floristic community (ADUAN et al., 2003; CUNHA et al., 2009; PAIVA; FARIA, 2007). In the fragment being studied, the mean carbon content found in

Cerne, Lavras, v. 19, n. 2, p. 237-245, abr./jun. 2013 
the soil in the $0-100 \mathrm{~cm}$ depth interval was $4.21 \%$, while the carbon stock was $90.46 \mathrm{Mg} \mathrm{ha}^{-1}$. Paiva and Faria (2007) found estimated carbon stock values of $271.23 \mathrm{Mg} \mathrm{ha}^{-1}$ in the $0-200 \mathrm{~cm}$ layer, for a fragment of cerrado sensu stricto in the Federal District, noting that these estimates were based on samples collected from up to $20 \mathrm{~cm}$ down. The same authors, as adapted from Castro (1996), found values close to $95 \mathrm{Mg} \mathrm{ha}^{-1}$ of $\mathrm{C}$ in the $0-200 \mathrm{~cm}$ depth layer, for cerradão soils. These values are close to results found in this study.

When soil samples were analyzed as per layer separately, it was in the $0-10 \mathrm{~cm}$ layer that the highest carbon content was found (2.59\%). The mean carbon stock in it was $21.92 \mathrm{Mgha}^{-1}$, accounting for around $24 \%$ of all carbon stocked in soil up to a depth of $100 \mathrm{~cm}$ down (Table 3). Paiva and Faria (2007) found higher carbon contents in the $20-40 \mathrm{~cm}$ layer, for soils of cerrado sensu stricto in the Federal District. Comparatively, according to Lima (2004), carbon contents under native forest, pastureland and eucalyptus environments were higher in the topmost soil layer than in other layers. Higher carbon content in the topmost layer is partly due to higher concentration of organic matter on the ground, to larger amounts of leaf litter being deposited on the ground, and to low solubility and mobility of residue and organic compounds deposited by the shoot portion into deeper layers of the cerradão soil. The fact that processes involving humus formation and organic matter adsorption are intenser in topmost layers than in deeper layers should also be taken into account (STEVENSON, 1994). However, some authors argue that depths holding greater carbon concentrations will vary according to each floristic community (LAL, 2007; MARCHIORI JÚNIOR; MELO, 1999; MELO; DURIGAN, 2006; NOVAES FILHO et al., 2007; ZHENG et al., 2007). According to them, this can be explained by variations in each floristic community as to root system distribution and by exudation of organic compounds along the profile of different soil layers.

Data in Tables 3 and 4 reveal that when the soil is subdivided into equally thick layers, $10 \mathrm{~cm}$ in this case, carbon content in the topmost soil layer is around 5 times higher than in the deepest soil layer. If compared to the second layer $(10-20 \mathrm{~cm})$, carbon content in the topmost layer is more than twofold higher than in the next layer.

Table 3 - Carbon contents in the soil, for each plot and soil layer, and descriptive statistics of data.

Tabela 3 - Teores de carbono em solo para cada parcela e camada de solo, e estatística descritiva dos dados levantados.

\begin{tabular}{|c|c|c|c|c|c|c|}
\hline \multirow{2}{*}{ Plots } & \multicolumn{6}{|c|}{ Sampling depth } \\
\hline & $0-10 \mathrm{~cm}$ & $10-20 \mathrm{~cm}$ & $20-40 \mathrm{~cm}$ & $40-60 \mathrm{~cm}$ & $60-100 \mathrm{~cm}$ & $0-100 \mathrm{~cm}$ \\
\hline 1 & 1.91 & 0.88 & 0.66 & 0.47 & 0.37 & 4.28 \\
\hline 5 & 2.24 & 1.17 & 0.69 & 0.72 & 0.51 & 5.33 \\
\hline 11 & 1.53 & 0.66 & 0.51 & 0.69 & 0.39 & 3.79 \\
\hline 12 & 1.56 & 0.86 & 0.53 & 0.51 & 0.42 & 3.88 \\
\hline 14 & 1.37 & 0.78 & 0.60 & 0.50 & 0.45 & 3.70 \\
\hline 16 & 2.07 & 0.76 & 0.61 & 0.48 & 0.40 & 4.32 \\
\hline 22 & 1.42 & 0.79 & 0.76 & 0.67 & 0.41 & 4.04 \\
\hline 26 & 0.97 & 0.74 & 0.65 & 0.45 & 0.37 & 3.18 \\
\hline 30 & 2.59 & 1.07 & 0.68 & 0.60 & 0.46 & 5.40 \\
\hline Mean & 1.74 & 0.86 & 0.63 & 0.57 & 0.42 & 4.21 \\
\hline Maximum & 2.59 & 1.17 & 0.76 & 0.72 & 0.51 & 5.40 \\
\hline Minimum & 0.97 & 0.66 & 0.51 & 0.45 & 0.37 & 3.18 \\
\hline SD & 0.50 & 0.17 & 0.08 & 0.10 & 0.05 & 0.74 \\
\hline CV (\%) & 3.45 & 5.18 & 8.06 & 5.39 & 9.29 & 5.72 \\
\hline
\end{tabular}

SD: standard deviation; CV(\%): coefficient of variation.

Cerne, Lavras, v. 19, n. 2, p. 237-245, abr./jun. 2013 
Table 4 - Soil density for each plot, and descriptive statistics of data.

Tabela 4 - Densidade do solo para cada parcela e estatística descritiva dos dados.

\begin{tabular}{cccccc}
\hline \multirow{2}{*}{ Plots } & \multicolumn{5}{c}{ Sampling depth } \\
\cline { 2 - 5 } & $0-10 \mathrm{~cm}$ & $10-20 \mathrm{~cm}$ & $20-40 \mathrm{~cm}$ & $40-60 \mathrm{~cm}$ & $60-100 \mathrm{~cm}$ \\
\hline 1 & 1.18 & 1.31 & 1.32 & 1.32 & 1.39 \\
5 & 1.1 & 1.42 & 1.43 & 1.34 & 1.38 \\
11 & 1.37 & 1.31 & 1.34 & 1.39 & 1.42 \\
12 & 1.27 & 1.33 & 1.51 & 1.38 & 1.43 \\
14 & 1.3 & 1.37 & 1.4 & 1.43 & 1.45 \\
16 & 1.4 & 1.44 & 1.54 & 1.39 & 1.47 \\
22 & 1.28 & 1.24 & 1.41 & 1.47 & 1.49 \\
26 & 1.26 & 1.28 & 1.31 & 1.41 & 1.39 \\
30 & 1.19 & 1.15 & 1.41 & 1.39 & 1.44 \\
\hline Mean & 1.26 & 1.32 & 1.54 & 1.47 & 1.53 \\
\hline Maximum & 1.4 & 1.44 & 1.31 & 1.32 & 1.38 \\
\hline Minimum & 1.1 & 1.15 & 0.08 & 0.05 & 0.05 \\
\hline SD & 0.09 & 0.09 & 17.27 & 30.7 & 27.71 \\
\hline CV $(\%)$ & 13.68 & 14.7 & &
\end{tabular}

SD: standard deviation; CV(\%): coefficient of variation.

Since carbon stock is a function of density (Table 4), carbon content and layer thickness, the parameter soil density directly influences calculation of carbon stocks. One can thus infer that carbon stock up to a depth of 40 $\mathrm{cm}$ accounts for $56 \%$ of the total found in the $0-100 \mathrm{~cm}$ depth interval. By increasing the layer by $20 \mathrm{~cm}$, that is, up to a depth of $60 \mathrm{~cm}$, the carbon stocked there will then account for around $73 \%$ of all carbon stocked in the $0-100 \mathrm{~cm}$ depth interval.

In this study, soil was the compartment found to hold the highest carbon stock. In comparing total carbon stocks between soil, leaf litter and roots, soil accounted for $87.91 \%$ of all carbon stocked in the fragment. If considering soil and roots, soil accounted for $92.53 \%$ of all carbon present in these two matrices. Similarly to this result, Abdala et al. (1998) reported that soil is responsible for storing more than $90 \%$ of the carbon existing under leaf litter in cerrados.

The mean total carbon stock in the fragment is 139.69 $\mathrm{Mg} \mathrm{ha}^{-1}$, with soil being the main carbon sink, stocking $64.8 \%(90.26 \mathrm{MgC} / \mathrm{ha})$, followed by shoot portion, with $26.3 \%$ (36.78 MgC/ha), then roots, with $5.2 \%(7.30 \mathrm{MgC} / \mathrm{ha})$ and leaf litter, which stocks $3.7 \%$ $(5.23 \mathrm{MgC} / \mathrm{ha})$ of $\mathrm{C}$ in the cerradão fragment.

\section{CONCLUSIONS}

In this study, the shoot portion contributed the highest biomass stock, followed by roots and leaf litter.

The topmost soil layers had the highest $\mathrm{C}$ contents and the lowest density, which increased the deeper the soil profile.

The soil matrix held the highest $\mathrm{C}$ stock in the cerradão fragment, followed by shoot portion, roots and leaf litter.

\section{ACKNOWLEDGEMENTS}

We are in debt with CNPq, CAPES and FAPEMIG for financial support to this research and scholarships provided. Special thanks to all crew, trainees and students of the LEMAF-DCF-UFLA for supporting the activities of sampling and soil preparations before determinations of $\mathrm{C}$ in the Soil Organic Matter Laboratory-DCS-UFLA.

\section{REFERENCES}

ABDALA, G. C.; CALDAS, L. S.; HARIDASAN, M.; EITEN, G. Above a belowground organic matter and root: shoot ratio in a Cerrado in Central Brazil. Brasilian Journal of Ecology, São Paulo, v. 2, n. 1, p. 11-23, 1998.

Cerne, Lavras, v. 19, n. 2, p. 237-245, abr./jun. 2013 
ADUAN, E. A.; VILELA, M. de F.; KLINK, C. A. Ciclagem de carbono em ecossistemas terrestres: o caso do cerrado brasileiro. Planaltina: EMBRAPA Cerrados, 2003. 30 p.

CAMPOS, E. P. de; DUARTE, T. G.; NERI, A. V.; SILVA, A. F. de; MEIRA-NETO, J. A. A.; VALENTE, G. E. Composição florística de um trecho de cerradão e cerrado Sensu Sricto e sua relação com o solo na Floresta Nacional (FLONA) de Paraopeba, MG, Brasil. Revista Árvore, Viçosa, v. 30, n. 3, p. 471-479, maio/jun. 2006.

CARVALHO, L. G.; OLIVEIRA, M. S. de; ALVES, M. de C.; VIANELLO, R. L.; SEDIYAMA, G. C.; CASTRO NETO, P.; DANTAS, A. A. A. Clima. In: SCOLFORO, J. R.; CARVALHO, L. M. T.; OLIVEIRA, A. D. (Ed.). Zoneamento ecológicoeconômico do Estado de Minas Gerais: componentes geofísico e biótico. Lavras: UFLA, 2008. p. 89-101.

CARVAlHO, L. M. T. de; SCOLFORO, J. R.; ACERBI JÚNIOR, F. W.; SILVEIRA, E. M. de O.; OLIVEIRA, L. T. de. Análises espaciais e estatísticas da flora nativa em Minas Gerais. In: CARVALHO, L. M. T. de; SCOLFORO, J. R. (Ed.). Monitoramento da flora nativa. Lavras: UFLA, 2008. p. 25316.

CASTRO, E. A. Biomass, nutrient pools and response to fire in the Brazilian Cerrado. 1996. 118 f. Thesis (Ph.D.) - Oregon State University, Corvallis, 1996.

CUNHA, G. de M.; GAMA-RODRIGUES, C. A.; GAMARODRIGUES, F.; VELLOSO, A. C. X. Biomassa e estoque de carbono e nutrientes em Florestas Montana da Mata Atlântica na região norte do estado do Rio de Janeiro. Revista Brasileira de Ciência do Solo, Campinas, v. 33, p. 1157-1185, 2009.

CURI, N. et al. Solos, geologia, relevo e mineração. In: SCOLFORO, J. R.; CARVALHO, L. M. T.; OLIVEIRA, A. D. (Ed.). Zoneamento ecológico-econômico do Estado de Minas Gerais: componentes geofísico e biótico. Lavras: UFLA, 2008. p. 73-88.

FERNANDES, F. A.; CERRI, C. C.; FERNANDES, A. H. B. M. Alterações na matéria orgânica de um Podzol hidromórfico pelo uso com pastagens cultivadas no Pantanal Mato-Grossense. Pesquisa Agropecuária Brasileira, Brasília, v. 34, p. 1943$1951,1999$.

FERNANDES, F. A.; FERNANDES, A. H. B. M. Cálculo dos estoques de carbono do solo sob diferentes condições de manejo. Corumbá: EMBRAPA Pantanal, 2009. 4 p. (Comunicado Técnico, 69).

JANTALIA, C. P.; ALVES, B. J. R.; ZOTARELLI, L.; BODEY, R. M.; URQUIAGA, S. Mudanças no estoque de C do solo em áreas de produção de grãos: avaliação do impacto do manejo de solo. In: ALVES, B. J. R.; URQUIAGA, S.; AITA, C.; BODEY, R. M.; JANTALIA, C. P.; CAMARGO, F. A. O. (Ed.). Manejo de sistemas agrícolas: impacto no sequestro de $\mathrm{C}$ e nas emissões de gases do efeito estufa. Porto Alegre: EMBRAPAAgrobiologia, 2006. p. 35-57.

LAL, R. Carbon sequestration. Philosophical Transactions of the Royal Society B, London, v. 363, p. 815-830, 2008.

LIMA, A. M. N. Estoques de carbono e frações da matéria orgânica do solo sob povoamentos de eucalipto no Vale do Rio Doce, MG. 2004. 131 p. Dissertação (Mestrado em Solos e Nutrição de Plantas) - Universidade Federal de Viçosa, Viçosa, 2004.

LIMA, E. de S.; LIMA, H. S.; RATTER, J. A. Mudanças pósfogo na estrutura e composição da vegetação lenhosa em um cerrado mesotrófico, no período de cinco anos (1997-2002) em nova xavantina, MT. Cerne, Lavras, v. 15, n. 4, p. 468-480, 2009.

MARCHIORI JÚNIOR, M.; MELO, W. J. Carbono, carbono da biomassa microbiana e atividade enzimática em um solo sob mata natural, pastagem e cultura do algodoeiro. Revista Brasileira de Ciência do Solo, Campinas, v. 23, p. 257-236, 1999.

MARIMON JUNIOR, B. H.; HARIDASAN, M. Comparação da vegetação arbórea e características edáficas de um cerradão e um cerrado Sensu Stricto em áreas adjacentes sobre solo distrófico no leste de Mato Grosso, Brasil. Acta Botanica Brasilica, Porto Alegre, v. 19, p. 913-926, 2005.

MELO, A. C. G. de; DURIGAN, G. Fixação de carbono em reflorestamentos de matas ciliares no Vale do Paranapanema, SP, Brazil. Scientia Forestalis, Piracicaba, v. 71, p. 149-154, 2006.

NOVAES FILHO, J. P.; SELVA, E. C.; COUTO, E. G.; LEHMANN, J.; JOHNSON, M. S.; RIHA, S. J. Distribuição espacial de carbono em solo sob floresta primária na Amazônia Meridional. Revista Árvore, Viçosa, v. 31, n. 1, p. 83-92, jan./fev. 2007.

OTTMAR, R. D.; VIHNANEK, R. E.; MIRANDA, H. S.; SATO, M. N.; ANDRADE, S. M. A. Séries de estéreo-fotografias para quantificar a biomassa da vegetação do cerrado no Brasil Central. Brasília: USDA; USAID; UnB, 2001. 88 p.

Cerne, Lavras, v. 19, n. 2, p. 237-245, abr./jun. 2013 
PAIVA, A. O.; FARIA, G. E. de. Estoque de carbono do solo sob Cerrado Sensu Stricto no Distrito Federal, Brasil. Revista Trópica - Ciências Agrárias e Biológicas, Chapadinha, v. 1, p. 59-65, 2007.

REZENDE, A. V.; VALE, A. T. do; SANQUETTA, C. R.; FIGUEIREDO FILHO, A.; FELFILI, J. M. Comparison of mathematical models to volume, biomass and carbon stock estimation of the woody vegetation of a Cerrado Sensu Stricto in Brasília, DF. Scientia Forestalis, Piracicaba, v. 71, p. 65-76, 2006.

RUFINI, A. L.; SCOLFORO, J. R. S.; OLIVEIRA, A. D. de; MELLO, J. M. de. Equações volumétricas para o cerrado Sensu Stricto em Minas Gerais. Cerne, Lavras, v. 16, n. 1, p. 1-11, 2010.

SCOLFORO, J. R.; MELLO, J. M. de; OLIVEIRA, A. D. de; PEREIRA, R. M.; SOUSA, F. N. de; GUEDES, I. C. de L. Volumetria, peso de matéria seca e carbono. In: SCOLFORO, J. R.; MELLO, J. M. de; OLIVEIRA, A. D. (Ed.). Florística, estrutura, diversidade, similaridade, distribuição diamétrica e de altura, volumetria, tendências de crescimento e áreas aptas para manejo florestal. Lavras: UFLA, 2008a. p. 361-439.

SCOLFORO, J. R.; RUFINI, A. L.; MELlO, J. M. de; OLIVEIRA, A. D. de; SILVA, C. P. de C. Equações para estimar o volume de madeira das fisionomias, em Minas Gerais. In: SCOLFORO, J. R.; OLIVEIRA, A. D.; ACERBI JÚNIOR, F. W. (Ed.). Inventário florestal de Minas Gerais: equações de volume, peso de matéria seca e carbono para diferentes fisionomias da flora nativa. Lavras: UFLA, 2008b. p. 67-101.
SCOLFORO, J. R.; RUFINI, A. L.; MELlO, J. M. de; OliVEIRA, A. D. de; SILVA, C. P. de C. Equações para quantidade de carbono das fisionomias, em Minas Gerais. In: SCOLFORO, J. R.; OLIVEIRA, A. D.; ACERBI JÚNIOR, F. W. (Ed.). Inventário florestal de Minas Gerais: equações de volume, peso de matéria seca e carbono para diferentes fisionomias da flora nativa. Lavras: UFLA, 2008c. p. 103-114.

SCOLFORO, J. R. S.; THIERSCH, C. R.; KANEGAE JUNIOR, H.; OLIVEIRA, A. D.; CARVALHO, F. H. Sistema de manejo para floresta nativa - SISNAT. In: CONGRESSO FLORESTAL BRASILEIRO, 8., 2003, São Paulo. Anais... São Paulo: SBS, 2003. p. $210-229$.

SOUZA, P. B. de; SAPORETTI JUNIOR, A. W.; SOARES, M. P.; VIANA, R. H. O.; CAMARGOS, V. L. de; MEIRA BETO, J. A. A. Florística de uma área de cerradão da Floresta Nacional de Paraopeba, Minas Gerais. Cerne, Lavras, v. 16, n. 1, p. 8693, jan./mar. 2010.

STEVENSON, F. J. Humus chemistry: genesis, composition, reactions. New York: J. Wiley, 1994. 496 p.

VELDKAMP, E. Organic carbon turnover in three tropical soils under pasture after deforestation. Soil Science Society of America Journal, Madison, v. 58, p. 175-180, 1994.

ZHENG, H.; OUYANG, Z.; XU, W.; WANG, X.; MIAO, H.; LI, $\mathrm{X}$.; TIAN, Y. Variation of carbon storage by different reforestation types in the hilly red soil region of southern Chine. Forest Ecology and Management, Amsterdam, v. 255, p. 1113-1121, 2008.

Cerne, Lavras, v. 19, n. 2, p. 237-245, abr./jun. 2013 
